\title{
In-Place Oil Shale Resources Underlying Federal Lands in the Green River and Washakie Basins, Southwestern Wyoming
}

Using a geologic-based assessment methodology, the U.S. Geological Survey estimated an in-place oil shale resource of 906 billion barrels under Federal mineral rights, or 62 percent of the total oil shale in place, in the Green River and Washakie Basins, Wyoming. More than 67 percent of the total oil shale in-place resource, or 969 billion barrels, is under Federal surface management.

\section{Introduction}

The U.S. Geological Survey (USGS) recently (2011) estimated the in-place oil shale resources, regardless of grade, in the Eocene Green River Formation of the Green River and Washakie Basins, southwestern Wyoming (fig. 1) at about 1.45 trillion barrels of oil (Johnson and others, 2011). The oil shale interval within the formation was subdivided into three zones, in ascending order: (1) Tipton Shale Member, (2) Wilkins Peak Member, and (3) LaClede Bed of Laney Member (fig. 2); each zone was assessed separately (table 1). Using geographic information systems (GIS) technology, several subsets of the total volume of 1.45 trillion barrels were calculated by merging the oil shale resource data with Bureau of Land Management (BLM) surface and subsurface ownership files (Bureau of Land Management, 2011). Because of the complex nature of mineral estate ownership, only those areas where the Federal Government retains rights to all minerals as defined by the
BLM were assessed as federally owned. This resulted in a minimum estimate of Federal oil shale resources.

\section{Resources Underlying Federal Lands}

Table 1 lists several subtotals of the total estimated 1.45 trillion barrels of oil in the Green River Formation:

1. About 906 billion barrels (62 percent) are federally owned.

2. About 969 billion barrels (67 percent) are located under Federal surface administered lands.

3. About 133 billion barrels (9 percent) are in strata that contain more than 15 gallons per ton (GPT) of rock, of which about 72 billion barrels are under Federal mineral (subsurface) ownership.

The 15 GPT estimates include only those areas where the weighted average of an entire assessed zone exceeds that minimum cutoff. In areas where the entire zone does not meet the minimum criteria, some oil shale intervals of significant thickness could exist within zones that exceed these minimum cutoffs. For example, a 30 -foot interval within an oil shale zone might exceed 15 GPT, but if the entire zone averages less than 15 GPT, these resources are not included in the 15 GPT subtotals, although they might be exploited in the future.

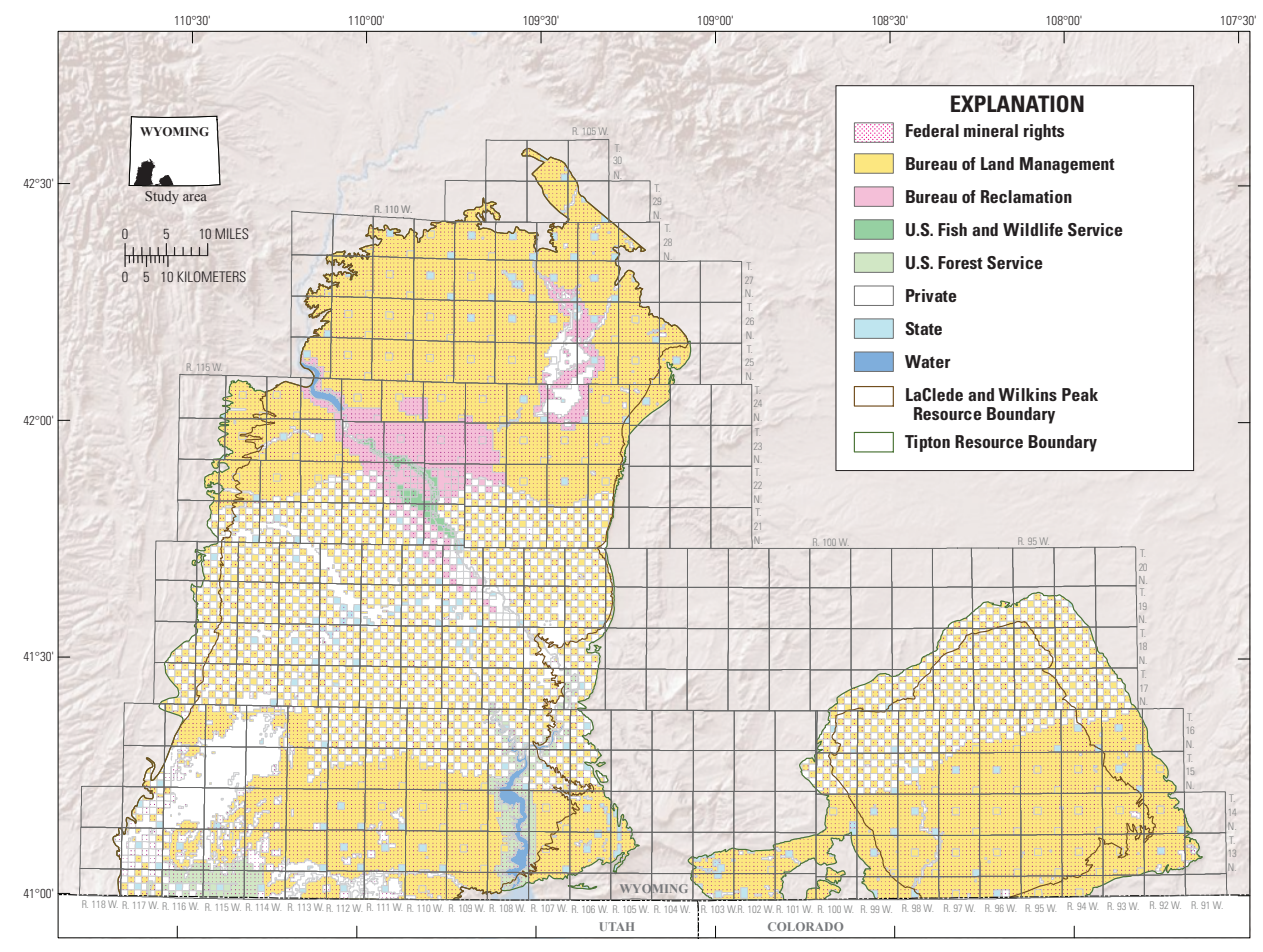

\section{References Cited}

Bureau of Land Management, 2011, Wyoming surface and mineral statusstate-owns.zip: Bureau of Land Management database, accessed May 2, 2011, at http://www.blm.gov/wy/st/en/resources/ public_room/gis/datagis/state/state-own. html.

Johnson, R.C., Mercier, T.J., and Brownfield, M.E., 2011, Assessment of in-place oil shale resources of the Green River Formation, Greater Green River Basin in Wyoming, Colorado, and Utah: U.S. Geological Survey Fact Sheet 2011-3063, $4 \mathrm{p}$.

Figure 1. Surface management and Federal mineral rights of oil shale resources in the Eocene Green River Formation, Green River and Washakie Basins, Wyoming. 


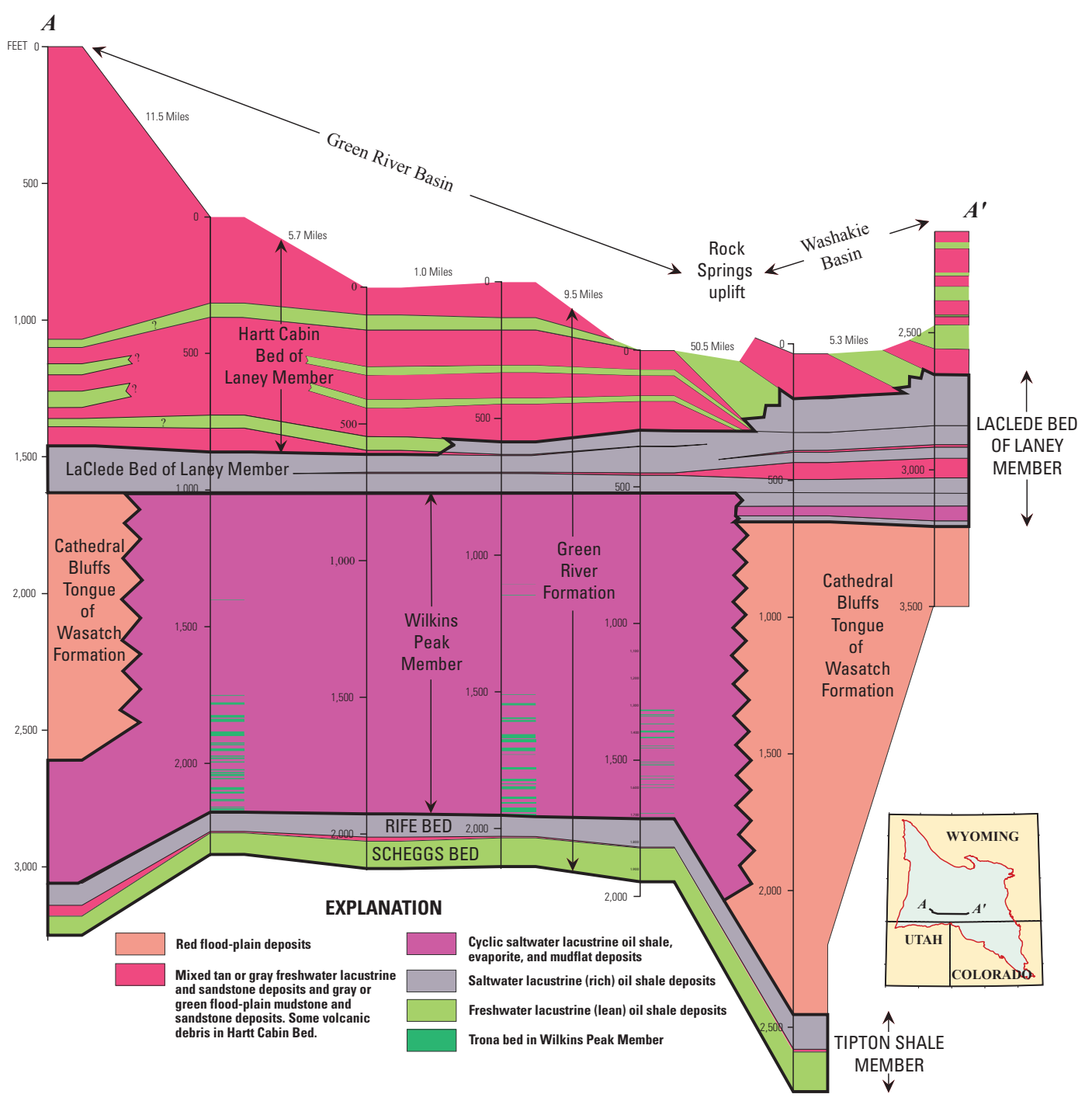

Figure 2. East-west stratigraphic cross section showing stratigraphic boundaries of the three oil shale units assessed (heavy black outlines) and related stratigraphic units (modified from Johnson and others, 2011). Outline in red on index map shows the Greater Green River Basin.

Table 1. Oil shale resources under federally managed lands and under Federal mineral rights in the Green River and Washakie Basins, Wyoming.

[Resource figures are in millions of barrels; resources are reported to four significant figures and may not equal the sum of the components, because of independent rounding; \%, percent; $\geq$, greater than or equal to; GPT, gallons per ton]

\begin{tabular}{|c|c|c|c|c|c|c|c|c|c|c|}
\hline \multirow[b]{3}{*}{$\begin{array}{c}\text { Oil shale zone } \\
\text { (Green River Formation) }\end{array}$} & \multicolumn{5}{|c|}{ All oil yields } & \multirow{2}{*}{\multicolumn{5}{|c|}{$\begin{array}{r}\text { Oil yield of } 15 \text { gallons per ton or greater } \\
\text { Federal mineral }\end{array}$}} \\
\hline & \multirow[b]{2}{*}{$\begin{array}{l}\text { Total oil } \\
\text { in place }\end{array}$} & \multicolumn{2}{|c|}{ Federal mineral } & \multicolumn{2}{|c|}{ Federal surface } & & & & & \\
\hline & & $\begin{array}{l}\text { Oil in } \\
\text { place }\end{array}$ & $\begin{array}{c}\text { As } \% \\
\text { of total } \\
\text { in } \\
\text { place }\end{array}$ & $\begin{array}{l}\text { Oil in } \\
\text { place }\end{array}$ & $\begin{array}{c}\text { As } \% \\
\text { of total } \\
\text { in } \\
\text { place }\end{array}$ & $\begin{array}{l}\text { Oil in } \\
\text { place }\end{array}$ & $\begin{array}{l}\text { As } \% \\
\text { of total } \\
\text { in } \\
\text { place }\end{array}$ & $\begin{array}{l}\text { Oil in } \\
\text { place }\end{array}$ & $\begin{array}{c}\text { As } \% \\
\text { of total } \\
\text { in } \\
\text { place }\end{array}$ & $\begin{array}{c}\text { "As } \% \\
\text { of } \\
\geq 15 \\
\text { GPT" }\end{array}$ \\
\hline LaClede Bed of Laney Member & 377,200 & 270,800 & 72 & 286,600 & 76 & 17,030 & 5 & 10,410 & 3 & 61 \\
\hline Tipton Shale Member & 362,800 & 217,300 & 60 & 231,800 & 64 & 111,100 & 31 & 57,800 & 16 & 52 \\
\hline Total & $1,451,000$ & 906,100 & 62 & 968,500 & 67 & 132,500 & 9 & 72,170 & 5 & 54 \\
\hline
\end{tabular}

\section{For Additional Information}

Supporting geologic studies of the oil shale-bearing units, assessment units, oil shale analysis, and the methodology used in assessing the oil shale resources in the Green River and Washakie Basins are in progress. Assessment results are available at the USGS Central Energy Resources Science Center website at $h t t p: / /$ energy.cr.usgs.gov/other/oil_shale/.

\section{Contact Information}

For further information, contact Tracey J. Mercier(tmercier@ usgs.gov), Ronald C. Johnson (rcjohnson@usgs.gov), or Michael E. Brownfield(mbrownfield@usgs.gov. 